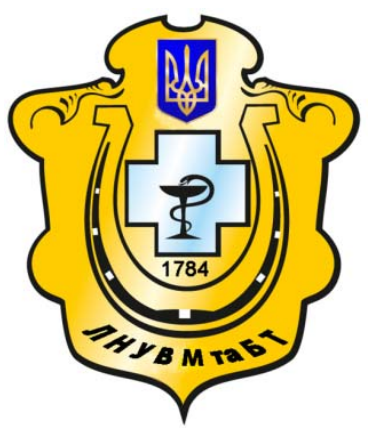

Науковий вісник Львівського національного університету ветеринарної медицини та біотехнологій імені С.3. Гжицького

Scientific Messenger of Lviv National University of Veterinary Medicine and Biotechnologies named after S.Z. Gzhytskyj

doi:10.15421/nvlvet7101

ISSN 2413-5550 print

ISSN 2518-1327 online

$\underline{\text { http://nvlvet.com.ua/ }}$

УДК 619:616:41:636.12:611.4.

\title{
Зміни властивостей еритроцитів у собак
}

\author{
М.В. Анфьорова ${ }^{1}$, В.І. Головаха 2 , О.В. Піддубняк ${ }^{2}$, М.Я. Тишківський ${ }^{2}$ \\ ua-andrea@ukr.net
}

\begin{abstract}
Одеський державний аграрний університет, вул. Пантелеймонівська, 13, м. Одеса, 65012, Україна; Білочерківський національний аграрний університет, пл. Соборна, 8/1, м. Біла Церква, 09111, Украӥна;
\end{abstract}

\begin{abstract}
Одними із важливих показників оцінки стану еритроцитопоезу є кислотна резистентність еритроцитів та їх популяиійний склад. Зміни цих показників найбільш вивчені у людей, великої рогатої худоби та коней. У дрібних домашніх тварин, зокрема собак ие питання висвітлено недостатньо. Тому вивчення змін иих тестів еритроцитопоезу є актуальним. Вивчення показників еритроцитопоезу проводили у службових собак різного віку (1,5-річні, 3 - 6-річного віку і старше 7річного віку). Крім вищевказаних показників, вивчали загальноприйняті. Встановлено, щяо у клінічно здорових собак загальноприйняті показники еритроцитопоезу (загальна кількість еритроцитів, уміст гемоглобіну, гематокритна величина, індекси «червоної» крові- МСH та МCV), незалежно від віку, істотно не змінюються. I все ж, у собак старше 7-річного віку відбуваються зміни зі сторони еритрочитопоезу. На це вказують популяційний склад еритроцитів та їх кислотна резистентність. Зокрема, у тварин збільшуеться кількість «старих» популяцій еритроцитів та відбуваються зміни їх гемолітичної резистентності. Еритрогрма у таких собак коротша, висота піку ї̈ на 15 \% більша, ніж у тварин молодшого віку. Сам пік - гострий, щчо вказує на швидке руйнування «молодих» червонокрівиів та дегенерацію ліпідної оболонки еритроичтів.
\end{abstract}

Ключові слова: собаки, вік, еритроцитопоез, еритроцити, гемоглобін, популяиії еритроцитів, кислотна резистентність, еритрограма.

\section{Изменения свойств эритроцитов у собак}

\author{
М.В. Анфёрова ${ }^{1}$, В.И. Головаха ${ }^{2}$, О.В. Пиддубняк ${ }^{2}$, М.Я. Тышкивский² \\ ua-andrea@ukr.net
}

Одесский государственный аграрный университет, ул. Пантелеймоновская, 13, г. Одесса, 65012, Украина; Белоцерковский национальный аграрный университет, пл. Соборная, 8/1, г. Белая Церковь, 09111, Украина

Одними из важных показателей оценки состояния эритроцитопоэза есть кислотная резистентность эритроцитов и их популяиионный состав. Изменения этих показателей наиболее изучены у людей, крупного рогатого скота и ломадей. У мелких домашних животных, в частности собак, этот вопрос изучен недостаточно. Поэтому изучение изменений этих тестов эритрочитопоэза есть актуальным. Изучение показателей эритрочитопоэза проводили у служебных собак различного возраста (животные 1,5 года, 3 - 6 лет и старше 7 лет). Кроме вышеуказанных показателей, изучали общепринятые. Установлено, что у клинически здоровых собак, не зависимо от возраста общепринятые показатели оценки эритроиитопоэза (общее количество эритрочитов, содержание гемоглобина, гематокритная величина, индексы «красной» крови - МСH и MCV) существенно не изменяются. И все же, у собак старше 7 лет происходят изменения в системе эритроцитопоэза. На это указывают популяиионный состав эритроиитов и их кислотная резистентность. В частности, у животных этой возрастной группы увеличивается количество «старых» популяций эритроцитов и изменяется их кислотная

\section{Citation:}

Anforova, M.V., Golovakha, V.I., Piddubnyak, O.V., Tyshkivskyy, M.J. (2016). Changing the properties of red cells in dogs. Scientific Messenger LNUVMBT named after S.Z. Gzhytskyj, 18, 3(71), 3-6. 
(гемолитическая) резистентность эритроичтов. Эритрограмма у таких животных короче, высота ее пика на 15\% больше, чем у животных младших возрастных групп. Пик эритрограммы острый, что указывает на быстрое разрушение «молодых» эритроцитов и последующую дегенерацию липидной оболочки «красных» кровяных клеток.

Ключевые слова: собаки, возраст, эритроцитопоэз, эритроциты, гемоглобин, популяциии эритроциттов, кислотная резистентность, эритрограмма.

\title{
Changing the properties of red cells in dogs
}

\author{
M.V. Anforova ${ }^{1}$, V.I. Golovakha², O.V. Piddubnyak ${ }^{2}$, M.J. Tyshkivskyy ${ }^{2}$ \\ ua-andrea@ukr.net
}

Odessa state agrarian university,

Panteleimonovska Str., 3, Odessa 65012, Ukraine;

Bila Tserkva national agrarian university,

Soborna sq., 8/1, Bila Tserkva, 09111, Ukraine

\begin{abstract}
One of the most important indicators is the assessment of erythrocytopoezis is acid resistance of erythrocytes and their population composition. Changes in these parameters are the most studied in humans, cattle and horses. In small animals, including dogs, the issue is not highlighted enough. Therefore, the study of changes of erytrocytopoezis by using these tests is important. The study erythrocytopoezis parameters was performed in dogs of all ages (1.5-year, $3-6$ years and 7 and older years of age). It was found that in clinically healthy dogs generall erythrocytopoezis indicators (total number of red blood cells, hemoglobin content, hematocrit value, the index «red» blood-MCH and MCV), regardless of age, did not significantly change. Yet in dogs older than 7 years there were found some changes on the the part of erythrocytopoezis. This was pointed by the changes of the population composition of red blood cells and their acid resistance. In particular, the animals showed an increased number of "old» populations of red blood cells and some changes of their hemolytic resistance. Particularly, the height of the erytrohram peak was $15 \%$ higher than in younger animals. The very peak was sharp, indicating the rapid destruction of the "young» red cells and degeneration of their lipid membranes.
\end{abstract}

Key words: dog, age, erythrocytopoezis, erythrocytes, hemoglobin, erythrocytes population, acid resistance, erythrohramma.

\section{Вступ}

Собаки в житті людини займають досить визначну роль, оскільки вони є найбільш відданими своєму господарю, є прекрасними охоронцями, мисливцями, рятувальниками, виконують пошукові роботи по знешкодженню вибухових пристроїв тощо (Bacanov, 1992).

Тому в Україні стало престижним розводити собак, особливо службових порід (Golovaha et al., 2001; Fasolja, 2006, 2007). Однак, економічні негаразди останніх років призвели до зубожіння населення, що негативно відобразилося на годівлі і утриманні собак. Саме негативні фактори здебільшого призводять до порушень метаболічних процесів у тварин, у регуляції яких безпосередньо активну участь бере система еритроцитопоезу (Nimand and Suter, 2001; Antonjak, 2002). Оскільки еритроцити володіють значними компенсаторними властивостями, то, очевидно, існують особливості кількісного і якісного складу, «червонокрівців» (Moskalenko, 1999; Piddubnjak, 2007). На сьогодні у вітчизняній ветеринарній медицині висвітлені показники еритроцитопоезу в т.ч. кислотна резистентність еритроцитів та їх популяційний склад у людей , великої рогатої худоби, коней (Terskov and Gitel'zon, 1967; Sizova et al., 1980; Levchenko et al., 2001; Rozumnjuk, 2002; Pyddubnjak, 2009). В той же час, у дрібних домашніх тварин цьому питанню мало приділено уваги, що не дає можливостей конкретизувати особливість клітин «червоного» кісткового мозку до фізіологічних та патологічних станів (Uillard et al., 2004).

Мета роботи полягає у вивченні змін властивостей еритроцитів (кислотна резистентність) та віковий склад «червонокрівців» у собак у віковому аспекті.
Оскільки основою еритроцитопоезу є еритроцити, то його популяції залежать від фізико-хімічних властивостей ліпідної оболонки. Найбільш важлива властивість це стійкість ліпідної мембрани до дії гемолітиків (графічне зображення відсотка гемолізу еритроцитів за певний час - еритрограма) (Terskov and Gitel'zon, 1967; Levchenko et al., 2001).

\section{Матеріал і методи досліджень}

Дослідження проводили на клінічно здорових собаках службових порід, яких поділили на три групи: перша - тварини 1,5-річного віку; друга - 3 - 6річного віку і третя - собаки старше 7-річного віку.

У крові собак визначали кількість еритроцитів (пробірковий метод), їх популяційний склад - метод фракціонування у градієнті густини сахарози за I. Сизовою; кислотну резистентність еритроцитів - за А.I. Терським та I.I. Гітельзоном; кількість гемоглобіну (геміглобінціанідний метод), гематокритну величину (за Шклярем), математично підраховували вміст гемоглобіну в еритроциті $(M C H)$ та середній об'єм еритроцитів $(M C V)$.

\section{Результати та їх обговорення}

Нами встановлено, що кількість еритроцитів у собак 1,5-річного віку в середньому становила 5,9 \pm 0,34 Т/л. Приблизно такі ж значення загальної кількості еритроцитів були в собак другої і третьої груп (табл. 1). 
Показники еритроцитів і їх популяції у службових собак

\begin{tabular}{|l|c|c|c|c|}
\hline \multirow{2}{*}{ Група тварин } & \multirow{2}{*}{ Еритроцити, Т/л } & \multicolumn{3}{|c|}{ Популяційний склад еритроцитів, у проц. } \\
\cline { 3 - 5 } & & «старі» & «зрілі» & «молоді» \\
\hline \multirow{2}{*}{ Перша } & $4,88-7,02$ & $8,9-15,8$ & $32,0-52,0$ & $40,5-52,4$ \\
& $5,9 \pm 0,34$ & $12,7 \pm 1,45$ & $40,9 \pm 2,76$ & $46,4 \pm 22,8$ \\
\hline \multirow{2}{*}{ Друга } & $5,8-7,21$ & $7,4-14,7$ & $31,7-42,1$ & $44,7-60,9$ \\
& $6,2 \pm 0,28$ & $19,1 \pm 1,40$ & $38,4 \pm 1,70$ & $51,5 \pm 2,66$ \\
\hline \multirow{2}{*}{ Третя } & $5,17-7,21$ & $15,7-28,7$ & $29,7-43,4$ & $33,0-41,6$ \\
& $6,1 \pm 0,46$ & $22,6 \pm 2,56^{\text {x } 0}$ & $38,5 \pm 2,78$ & $38,9 \pm 1,90 \times 0$ \\
\hline
\end{tabular}

Примітка. ${ }^{\mathrm{x}} \mathrm{p}<0,05$; порівняно 3 першою групою; . ${ }^{0} \mathrm{p}<0,05$ порівняно 3 другою групою

Якщо загальна кількість еритроцитів у тварин трьох груп не відрізнялася, то співвідношення популяцій еритроцитів у периферичній крові має деякі відмінності. Стосується це, насамперед, «старих» еритроцитів. Їх найбільше було у собак старше 7річного віку $-22,6 \pm 2,56 \%$, що, очевидно, пов'язано iз порушенням процесів дозрівання еритроцитів, внаслідок виснаження запасів ціанокобаламіну та фолієвої кислоти.

Кількість «зрілих» форм еритроцитів у собак усіх груп була в середньому на одному рівні (p < 0,5; табл. 1). А ось кількість «молодих» червонокрівців найменшою була у собак після 7-річного віку (на 7,5 і $12,6 \%$ порівняно 3 першою $\mathrm{i}$ другою групами; $\mathrm{p}<0,05)$.

Зміни в популяційному складі еритроцитів впливають і на кислотну резистентність «червоних» клітин крові, адже час гемолізу залежить від їх віку, що й спричинює швидкість руйнування внутрішньоклітинних структур і опірність мембрани щодо підвищеного тиску всередині клітини (Rozumnjuk, 2002; Suda et al., 2002).

Аналіз графіків еритрограми вказує на те, що час основного піку у собак 1,5-річного віку наставав на 4,5 хв; висота його складала $25 \%$. Повний гемоліз еритроцитів завершувався на 7 хв (рис. 1). Подібний графік був і у собак 3 - 6-річного віку. Що стосується третьої групи, то тут нами виявлено деякі зміни у еритрограмі. Зокрема, висота піку становила 40\% (на $15 \%$ більше, ніж у попередніх груп). Повний гемоліз еритроцитів завершувався на 6,5 хв, що на 0,5 хв раніше порівняно з собаками першої і другої груп. Наявність гострого піку вказує на те, що «молоді» еритроцити швидко руйнуються. Це пов'язано з тим, що у собак старшого віку мембрана «молодих» популяцій еритроцитів виснажена щодо ліпідних компонентів (в основному фосфоліпідів) (Suda et al., 2002). Отже, у собак старше 7-річного віку відбуваються процеси дегенерації «червоного» кісткового мозку, хоча загальна кількість еритроцитів у нормі.

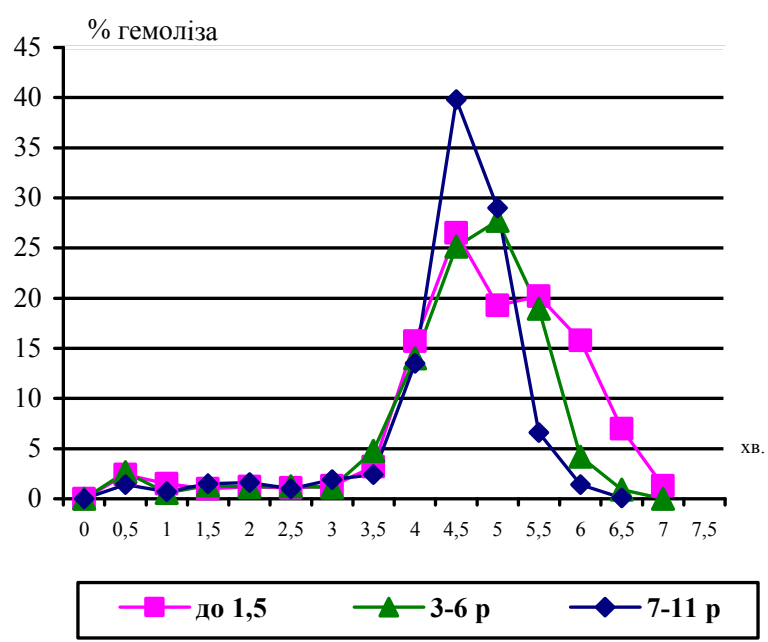

\section{Рис.1. Еритрограми у собак}

Уміст гемоглобіну в крові собак першої групи в середньому становив 138,0 \pm 5,51 г/л. Подібні значення дихального ферменту крові були і в собак другої та третьої груп. Слід зазначити, що в усіх собак рівень гемоглобіну був у межах фізіологічних коливань.

Для оцінки загального об'єму еритроцитів визначали гематокритну величину. Цей показник у собак першої-третьої груп був у середньому однаковим (табл. 2).

Вираховуючи індекси «червоної» крові, які свідчать про інтенсивність дозрівання еритроцитів та насичення їх гемоглобіном в кістковому мозку - $\mathrm{MCH}$ і $M C V$ у тварин усіх груп теж істотно не відрізнялися (табл. 2; $<<0,5$ ).

Показники «червоної» крові у собак

\begin{tabular}{|l|c|c|c|c|}
\hline \multicolumn{1}{|c|}{ Група тварин } & $\begin{array}{c}\text { Вміст гемоглобіну, } \\
\text { Г/л }\end{array}$ & $\begin{array}{c}M C H, \\
\text { ח/г }\end{array}$ & $\begin{array}{c}\text { Гематокритна } \\
\text { величина, } \%\end{array}$ & $\begin{array}{c}M C V, \\
\text { мкм }^{3}\end{array}$ \\
\hline \multirow{2}{*}{ Перша } & $126,0-152,0$ & $21,7-29,9$ & $34,0-40,0$ & $55,6-69,1$ \\
& $138,0 \pm 5,51$ & $23,5 \pm 1,56$ & $37,0 \pm 1,25$ & $62,7 \pm 3,68$ \\
\hline \multirow{2}{*}{ Друга } & $130,0-136,0$ & $18,0-28,6$ & $33,0-46,0$ & $55,5-77,6$ \\
& $146,0 \pm 4,68$ & $23,6 \pm 1,15$ & $39,4 \pm 1,86$ & $63,5 \pm 2,86$ \\
\hline \multirow{2}{*}{ Третя } & $135,0-160,0$ & $18,7-26,7$ & $32,0-46,0$ & $55,7-72,8$ \\
& $146,0 \pm 9,40$ & $24,2 \pm 2,04$ & $39,2 \pm 2,36$ & $64,1 \pm 22,23$ \\
\hline
\end{tabular}




\section{Висновки}

Таким чином, проведені дослідження показують, що загальноприйняті показники еритроцитопоезу (загальна кількість еритроцитів, уміст гемоглобіну, гематокритна величина, індекси «червоної» крові) у клінічно здорових собак, незалежно від віку, істотно не змінюються. I все ж, у собак старше 7-річного віку відбуваються зміни зі сторони еритроцитопоезу. На це вказують популяційний склад еритроцитів та їх кислотна резистентність. Зокрема, у тварин збільшується кількість «старих» популяцій еритроцитів та відбуваються зміни їх гемолітичної резистентності. Еритрограма у таких тварин коротка, висота піку іiї на $15 \%$ більша, ніж у тварин молодшого віку. Сам пік гострий, що вказує на швидке руйнування «молодих» популяцій та дегенерацію ліпідної оболонки еритроцитів.

Подальші наукові дослідження будуть спрямовані на вивчення показників ферумотрансферинового комплексу та метаболізму інших гемопоетичних мікроелементів.

\section{Бібліографічні посилання}

Bacanov. N.P. (1992). Vashy domashnye chetveronogye druz'ja. SPb.: Lenynyzdat (in Russian).

Fasolja, V.P. (2007). Dejaki pokaznyky gemopoezu u sobak sluzhbovyh porid. Poltav. derzh. ag-ran. akad. Poltava. 3, 76-80 (in Ukrainian).

Golovaha, V.I., Solovjova, L.M., Dykyj, O.A., Fasolja, V.P. (2001). Pokaznyky gemopoezu ta funkcii' pechinky u sobak sluzhbovyh porid. Visnyk Bilocerkiv. derzh. agrar. un-tu: Zb. nauk. prac'. 16, 46-51 (in Ukrainian).

Fasolja, V.P. (2006). Rezul'taty dyspanseryzacii' cucenjat sluzhbovyh porid vikom vid pivtora do shesty misjaciv. Visnyk Bilocerkiv. derzh. agrar. un-tu: Zb. nauk. prac'. 40, 211-217 (in Ukrainian).

Antonjak, G.L. (2002). Osoblyvosti gemopoezu u tvaryn na rannih stadijah postnatal'nogo rozvytku: av-toref. dys. na zdobuttja nauk. stupenja d-ra biol. nauk: spec. 14.01.31. "Gematologija ta transfuziologija». L'viv, 29 (in Ukrainian).

Nimand, H.G., Suter, P.B. (2001). Bolezni sobak. M: Akvarium (in Russian).
Piddubnjak, O.V. (2007). Zminy vlastyvostej erytrocytiv u kobyl. Nauk. visnyk L'viv. nac. un-tu vet. medycyny ta biotehnologij im. S.Z. Gzhyc'kogo. 9, 2(33), 227-231 (in Ukrainian)

Moskalenko, V.P. (1999). Strukturno-funkcional'ni vlastyvosti erytrocytiv u zdorovyh i hvoryh na anemiju teljat ta i'h zminy pry likuvanni: avtoref. dys. na zdobuttja nauk. stupenja kand. vet. nauk: spec. 16.00.01. «Diagnostyka i terapija tvaryn». Bila Cerkva, 18 (in Ukrainian).

Terskov, I.A., Gitel'zon, I.I. (1967). Znachenie dispersnyh metodov analiza jeritrocitov $\mathrm{v}$ norme $\mathrm{i}$ patologii. Voprosy biofiziki, biohimii i patologii jeritrocitov. M.: Nauka, 41-48 (in Russian).

Sizova, I.A., Kamenskaja, V.V., Fedjakov, V.I. (1980). Bezapparaturnyj sposob frakcionirovanija krasnyh kletok krovi v gradiente plotnosti saharozy. Izv. Sib. otd. AN SSSR. 3(15), 119-122 (in Russian).

Rozumnjuk, A.V. (2002). Struktura i funkcional'ni vlastyvosti erytrocytiv ta i'h zminy pry likuvanni teljat, hvoryh na bronhopnevmoniju: avtoref. dys. na zdobuttja nauk. stupenja kand. vet. nauk: spec. 16.00.01. «Diagnostyka i terapija tvaryn». Bila Cerkva, 18 (in Ukrainian).

Levchenko, V.I., Rozumnjuk, A.V., Golovaha, V.I., Tyhonjuk, T.V. (2001). Sklad i vlastyvosti erytrocytiv arterial'noi' ta venoznoi' krovi u klinichno zdorovyh teljat. Visnyk Bilocerkivs'kogo derzh. agrar. un-tu. 8, 218-223 (in Ukrainian).

Pyddubnjak, O.V. (2009). Pokaznyky gemopoezu u konej ta diagnostyka jogo zmin za patologii': avtoref. dys. na zdobuttja nauk. stupenja kand. vet. nauk: spec. 16.00.01. «Diagnostyka i terapija tvaryn». - Bila Cerkva, 19 (in Ukrainian).

Uillard, M., Tvetden, G., Tornval'd, G. (2004). Laboratornaja diagnostika $\mathrm{v}$ klinike melkih domashnih zhivotnyh. Pod. red. d-ra biol. nauk V.V. Makarova; Per. s angl. L.I. Evelevoj, G.N. Pimochkinoj, E.V. Sviridovoj. M.: Akvarium Buk (in Russian).

Suda, T., Akamatsu, A.., Nakaya, Y. (2002). Alterations in erythrocyte membrane lipid and its fragility in a patient with familial lecithin cholesterol acytransferase (LCAT) deficiency. J. Med. Invest. 49(3-4), 147-155. Стаття надійшла до редакиії 1.10.2016 